\title{
An Exploration of the Factors Hindering Students' Lesson Comprehension in EMI Classes
}

Tran Ngoc Tien

Hoa Sen University, Viet Nam

tien.tranngoc@hoasen.edu.vn

\section{Tran Thi Bao Trinh}

Hoa Sen University, Viet Nam

trinh.ttb3143@sinhvien.hoasen.edu.vn

Bien Thi Thanh Mai

Hoa Sen University, Viet Nam

mai.bienthithanh@hoasen.edu.vn

\section{DOI: http://doi.org/10.36892/ijlls.v2i3.317}

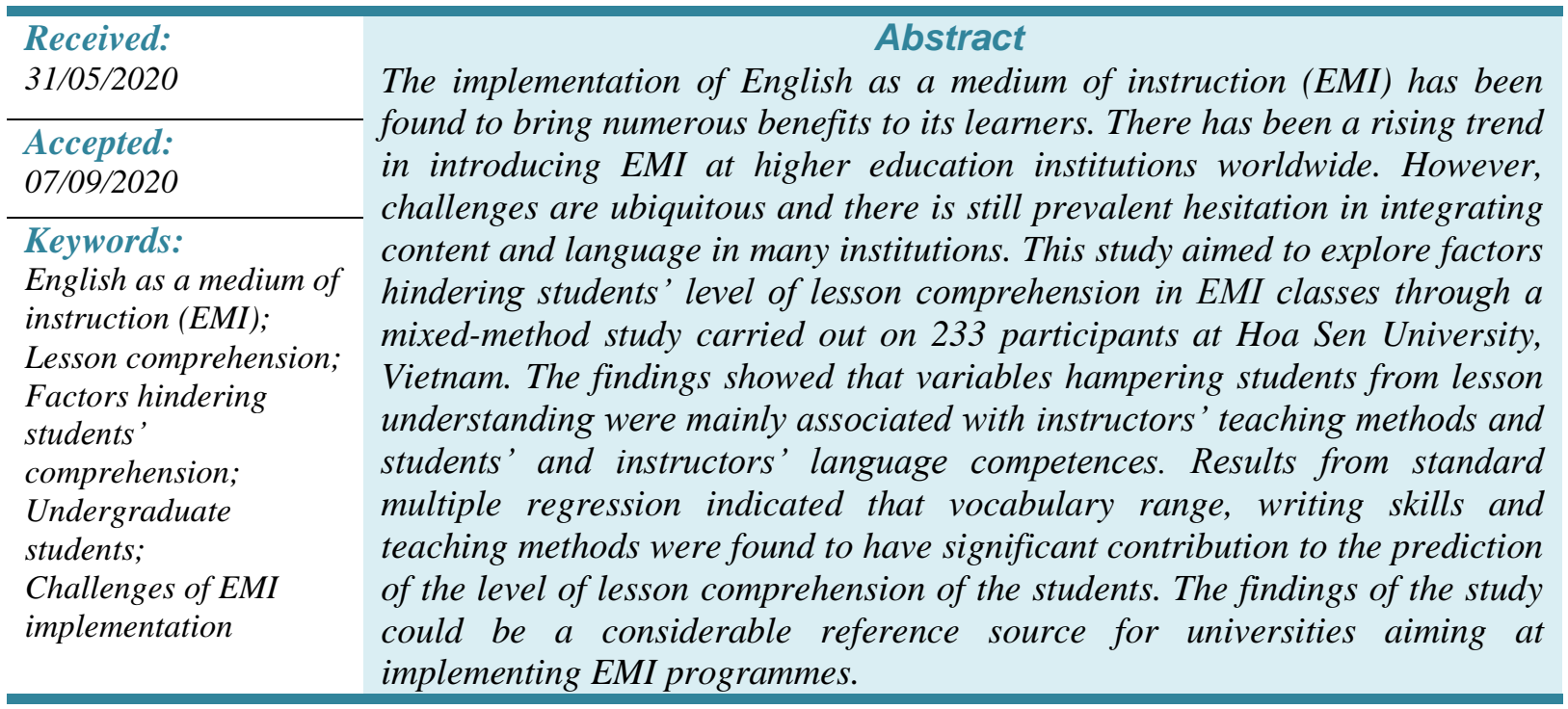

\section{INTRODUCTION}

English as a medium of instruction (EMI), according to Macaro, Curle, Pun, An, and Dearden (2018), is "the use of the English language to teach academic subjects (other than English itself) in countries or jurisdictions where the first language of the majority of the population is not English" (p. 37). Dearden (2014) shared almost the same meaning when defining EMI as a way to teach knowledge content courses in English in countries where English is not a first or an official language. The implementation of EMI has been proved to provide numerous benefits including exposing English language environment to students (Ibrahim, 2001), improving students' language competences (Corrales, Rey \& Escamilla, 2016; Rogier, 2012), developing students' learning strategies (Hu \& Lei, 2014), increasing students' learning motivation (Dorasamy, 2012; Huang, 2015) and helping the learners absorb enormous knowledge (Byun, Chu, Kim, Park, Kim \& Jung, 2011; Galloway, Kriukow \& Numajiri, 2017).

English language has been widely used as a medium instruction in various fields, from policy, business, education to society since the end of World War II (Mellion, 2008) and has become one of the treasures of each nation in the globalization race (Bradford, 2013). In a study conducted on 2,218 higher education institutions in 27 European countries where English was not the national language, Wächter and Maiworm (2008) discovered that 2,389 
programmes in Europe were entirely conducted in English in 2007. The number experienced a significant increase from 725 programmes offered in English in 2002 (Wächte, \& Maiworm, 2002). In 2014, the number of programmes taught in English among the European countries sharply surged to 8,089 (Wächte, \& Maiworm, 2014). The main motives for implementing English-taught progogrammes were to attract international students, to prepare domestic students for the global labour market and to make the institutional profile more competitive (Wächter \& Maiworm, 2008).

Similarly, the number of HEIs (Higher Education Institutions) adopted English as a medium of instruction has grown exponentially, especially in Asia where there are many nonEnglish speaking countries. Korean HEIs had promoted EMI courses up to $35 \%$ of all curricula by 2010 (Joe \& Lee, 2012). Likewise, other nations or territory such as Japan, China, Taiwan and Singapore have expanded EMI in universities as broadly as possible to increase the competitiveness of higher education system in the globalization race (Bradford, 2013; Byun \& Kim, 2011; Chang, 2010). Graddol (1997) believes that the worldwide trend of the global education in universities is using English as a medium of instruction for teaching knowledge content.

Improving foreign language proficiency of the Vietnamese citizens, particularly English, has long been considered as a key in sustaining national identity and promoting national human capital (Phan, 2014). Vietnamese Government also issued Decision No. 1400/QD-TTG to ratify the national project 2020 on promoting the language teaching and learning (Government of Vietnam, 2008). There has been a rising tendency in implementing EMI in training programs at tertiary institutions in Vietnam (Nguyen, Walkinshaw \& Pham, 2017). However, hesitation still remains in introducing EMI programs when universities consider between gains and losses (Wilkinson, 2013). This is due to the inadequate level of language among the Vietnamese learners (Phuong \& Nguyen, 2019). Within the context of Hoa Sen University (HSU), EMI has been implemented EMI since 2008; however, the scale is still limited in courses and not a whole programme. Many concerns still remain such as whether EMI is appropriately implemented, EMI makes positive impacts on students' learning process, HSU students prefer EMI classes to classes taught in Vietnamese language, or EMI brings more gains than losses.

This study aims to investigate the challenges that students of Hoa Sen University face in the current EMI-implemented programs at Hoa Sen University. The study also explores the extent that students could comprehend lessons taught in English and evaluate how well items of difficulties could significantly predict the research participants' lesson comprehension. The study can be of some significances. It redounds to the higher educational institutions, currently or potentially implementing EMI, to have comprehensive understanding of the EMI practices. From this, higher education institutions can issue appropriate policies addressing students' difficulties and assisting the learners to make the most of their EMI classes. The study can also add a reliable reference to the existing body of the literature in terms of challenges that students in a country where English is used as a second language encounter in EMI classrooms. Lecturers of EMI courses can also take the study results into their account to adjust their teaching methods and enhance their teaching quality.

\section{LITERATURE REVIEW}

\section{Limited Range of Vocabulary}

Among the numerous challenges faced by learners in the EMI classes, vocabulary plays the most significant role because learners do not have adequate word range to be able to understand EMI lectures (Chang, 2010). Similarly, Rogier (2012) added that students have problems with understanding EMI lessons due to insufficient vocabulary knowledge. Keuk and Tith (2013) also agreed that the shortage of vocabulary coupled with unclear contexts make students feel hard to comprehend the lesson and convey their opinions. A research 
conducted by Hellekjær (2010) on a number of Norway and German students discovered that the students found it difficult to read texts or take notes in EMI classes because of unknown words. It was argued by Coxhead and Boutorwick (2018) that without the suitable input from reading students have insufficient knowledge of words to deal with subject content. Hence, students tend to get lost in lecturers' speech and cannot take note by their own and wait for lecturers' writing key words or technical terms on board to copy (Chuang, 2015). In the context of Vietnam, limited vocabulary knowledge was found to be a greatest source of difficulty preventing students from not only understanding the knowledge content but also expressing their opinions comprehensively EMI classes (Phuong \& Nguyen, 2019).

\section{Inadequate Language Skills}

Students' inadequate language skills are also found to be among those of the great barriers in EMI classes. In fact, using English proficiency test and subject exam scores in their research, Rose, Curle, Aizawa and Thompson (2019) asserted that low English proficiency significantly influenced the success of EMI programs. According to Keuk and Tith (2013), reading skills seem the most difficult tasks for students because of grammatical differences between English and students' mother tongues. Besides, students encounter uncounted challenges in writing assignment when writing in a language not of their mother tongues (Al-Kahtany, Faruk \& Al Zumor, 2016; Rogier, 2012). Students' essays lack both diversified uses of vocabulary and critical thinking (Dorasamy, 2012). Keuk and Tith (2013) believed that it is the lack of accurate input and regular practice resulting in weak writing skills of students.

Kagwesage (2013) found that students in EMI classes have some difficulties in communication due to the lack of language skills. They can only produce single and simple word expressions when getting involved into classroom discussions. Additionally, learners are afraid of making mistakes when communicating in the language not of their mother tongues. This gradually make them feel inhibited and not confident in their speaking (Keuk \& Tith, 2013). Consequently, students seldom ask and answer questions, expand issues in discussions, and well-communicate in classes. Joe and Lee (2012) indicated that poor speaking ability prevents students from interacting with lecturers, so students often use mother tongue to ask and discuss in group.

Listening is a mean for learners to absorb knowledge during class time. It strongly influences the extent of lecture understanding of the learners especially in EMI classes. However, many students admit that they do not have good listening skills and this negatively influences their lesson understanding and course achievement (Kagwesage, 2013; Phuong \& Nguyen, 2019). Likewise, a research of Alanshory (2014) indicated that $77 \%$ students admit that listening skills hinder course acquisition and that 98\% EMI instructors believe students have trouble comprehending academic content in English due to inability of English listening.

\section{Teachers' Oral Skills}

Factors hindering students from understanding the lessons do not merely come from the students themselves. Hu (2019) concluded upon reviewing four empirical studies of EMI in Chinese universities that instructors need to be adequately capable of the EMI. Without it, instructors are not likely to "engage students in complex cognitive processes, scaffold their effort to master disciplinary knowledge or provide rich language input to develop advanced English proficiency in the students" $\mathrm{Hu}(2019, \mathrm{p} .8)$. A couple of factors have been found coming from the lecturers that make students struggle to understand the lessons. These are lecturers' oral skills and their teaching methods (Civan \& Coskun, 2016; Dorasamy, 2012).

Lecturers' poor oral skills are considered to be the main cause for the loss of students' understanding (Chang 2010; Civan \& Coskun 2016). According to Bradford (2013), over $80 \%$ of students indicates that lecturers' speaking skills are insufficient. Inaccurate 
pronunciation and shortage of vocabulary are two common problems. The limited vocabulary range makes lecturers have difficulties in expressing effectively, so they rarely paraphrase, explain clearly, and refine statements (Vu \& Burns, 2014). Another factor coming from lecturers making students feel challenging to keep up with instructor's lecture is their fast speed (Goodman, 2014; Kagwesage, 2013). Likewise, Vu \& Burns (2014) pointed out that lecturers' speed affects much not only students' comprehension but the learning attitudes as well. Sometimes, lecturers often feel anxious even though their English competences are more than enough to teach EMI subjects (Goodman, 2014).

\section{Teachers' Teaching Methods}

Teaching methods have found to make a significant contribution to students' lesson comprehension (Kim, Kweon \& Kim, 2017). Bradford (2019) even asserted that teaching methods, such as teaching practices which focus on interactive discussions, are considered more important for lesson comprehension than instructors' imperfect English ability or student listening skills. He argued for the necessity to pay greater attention to pedagogical measures for the success of EMI programs. Vu and Burn (2014) believed that lecturers are offered few opportunities of appropriate language training before taking EMI classes and they argued for the necessity of EMI pedagogy in order to avoid unclear guidance in EMI lessons. Specifically, code-switching method in EMI remains controversial. Some authors hold the view that code-switching is necessary for explaining difficult concept or challenging content because of exclusive use of English brought to difficulties in comprehension (Hu \& Lei 2014; Al-Kahtany et al. 2016). However, other researchers doubted that code switching may not be an appropriate pedagogical approach as it fails to facilitate learners' academic literacies (Kyeyune, 2010).

\section{Time Constraint}

Time limitation was found to play as a significant hindrance affecting the success of EMI classes in the research of Keuk and Tith (2013). It has been argued that EMI classes offer an inadequate duration for lecturers and students to work out the lessons. Similar finding was also found in the case of Dutch students. Learners admitted that they could not comprehend a large amount of information delivered in the class in a limited amount of time and respondents also claimed that more time should be allocated for the learners to finish class assignments (Wilkinson, 2005). Additionally, due to limited knowledge of both academic and specialized vocabulary, a large proportion of students spend extra time to read and understand textbooks and materials with the support of dictionaries or translation devices (Phuong \& Nguyen, 2019).

\section{METHODOLOGY}

\section{Methods Applied}

Mixed method was selected for this study because its benefits. According to HesseBiber (2010), this combination of quantitative and qualitative approaches can take advantages of strengths limit the disadvantages of each individual approach. Particularly, quantitative leads researchers to conclusion by analyzing figures and statistics which means the method allows the researchers to investigate a phenomenon with a wide range of research facets or items (Neuman, 2007). The survey gives researchers a chance to approach a great amount of data that need collecting and analyzing (Hesse-Biber, 2010). Qualitative research approach, on the other hand, focuses on gaining a various range of responses, which provides profound understanding of research issues through participants' views and thoughts (Berg, 2001; Creswell, 2012). The interview is implemented to find out insightful information which provides researchers a full explanation of what, why, where, and how specific phenomenon occurs (Neuman, 2007). 


\section{Instrument Construction}

The questionnaire was designed after analyzing literature and reviewing the major focus of the study. The questionnaire consisted of five sections. This included personal information, difficulties students encountered, benefits students gained, students' satisfaction, and three open ended questions for students to express their perceptions. More specifically, there are 40 questioned items in total related to of EMI classes, including two main types: rating scale and multiple choice. These closed-ended questions help to collect and code the basic background information of participants. For the scale of this paper, only 18 items of the first two sections related to the demographic background of the research participants and the difficulties students encountered in their EMI classes were selected for analysis.

All the items in the questionnaire were constructed by referring to the studies of previous research suitable for this study context. The content of the questionnaire was edited and double-checked using the content validity techniques by discussing with four university instructors who are knowledgeable of EMI and a group of six students from different majors and academic years who were taking EMI classes at the time of getting feedbacks. From the feedbacks of the instructors, students, the questionnaire was clarified in other that no ambiguity and misunderstanding remained. As a result, the final version of questionnaire was accomplished by considering whether questions covered all main aspects that the study aims to explore. Internal consistency reliability was employed in this study to check the consistency among the variables. This would help to see whether all the scale measures the same underlying attribute or not. The Cronbach alpha coefficient of 10 items concerning difficulties students encountered in their EMI classes used in this paper was .833. The figure proves that the scales have fairly good internal consistency.

\section{DATA COLLECTION}

Data collection was conducted via pencil-and-paper interviews, face-to-face interviews and group discussion. At the time of data collection, three faculties namely Economics and Business, Science and Engineering, and Tourism of Hoa Sen University offered EMI classes. Cluster sampling technique was used to pick up two EMI classes each faculty and all the students were approached for survey questionnaire. Cluster sampling was selected because it helps to pick up the respondents relatively equal from all three faculties. 300 questionnaires were printed out and distributed to the participants during their class time in May 2018. A cover letter was attached to each questionnaire to indicate the purposes of the study and ask for the consent of the participants in filling out the questionnaire. Furthermore, promises were also made to the participants that their information would be kept confidential under any circumstances and that the informants had their own rights whether to join in the study or not. A total of $282(94 \%)$ papers were returned and $233(77.6 \%)$ responses were used for analysis.

A total of 20 students from three faculties were also invited for group or individual interviews which were recorded or note-taken to reinforce the findings of the survey. The interviews were conducted in Vietnamese. Although all the informants had at least basic command of English when taking the EMI classes, interviews conducted in their native language would make them easier to discuss the issue of EMI implementation. This is also to make sure that no barrier would happen in terms of language to prevent the informants in expressing their viewpoints. Purposeful sampling technique was used to select the interviewed informants. The criteria for informants invited for the individual and group interviews were those who had experiences in taking EMI classes, had comprehensive understanding of EMI and had the willingness to share their viewpoints on the issues of EMI implementation. The informants invited for the interviews came from all the three faculties. This not only helped to diversify viewpoints but also ensured the balance among different students of different year levels and majors. The focuses of the interviews were to explore the informants' personal viewpoints, experiences and feelings towards the difficulties that they 
faced, the benefits that they believed that they gained in the EMI classes. The table below shows the general background of participants of this study including gender, student year, faculty, and the number of EMI courses taken at school.

Table 1. Distribution of Students Participating in the Survey

\begin{tabular}{|c|c|c|c|}
\hline & Sub-category & Frequency & Percentage \\
\hline \multirow[t]{3}{*}{ Gender } & Male & 108 & 46.4 \\
\hline & Female & 120 & 51.5 \\
\hline & Others & 5 & 2.1 \\
\hline \multirow[t]{4}{*}{ Student Year } & Freshman & 78 & 33.5 \\
\hline & Sophomore & 65 & 27.9 \\
\hline & Junior & 60 & 25.8 \\
\hline & Senior & 30 & 12.9 \\
\hline \multirow[t]{3}{*}{ Faculty } & Economics and Business & 84 & 36.1 \\
\hline & Science and Engineering & 68 & 29.2 \\
\hline & Tourism & 81 & 34.8 \\
\hline \multirow{4}{*}{$\begin{array}{l}\text { Number of EMI courses } \\
\text { taken }\end{array}$} & 1 course & 102 & 44.5 \\
\hline & 2 courses & 37 & 16.2 \\
\hline & 3 courses & 34 & 14.8 \\
\hline & 4 or more courses & 56 & 24.5 \\
\hline Total & & 233 & 100.0 \\
\hline
\end{tabular}

\section{DATA ANALYSIS}

SPSS version 22.0 was utilized to analyze data collected from the survey questionnaires. Particularly, descriptive analysis was employed to count some variables such as gender, year of learning, faculty, the number of EMI courses taken, and the frequencies of difficulties. Moreover, multiple regression was used to discover the correlation between challenges students faced in EMI courses and the overall EMI lesson comprehension. This also helped to evaluate how well items of challenges in taking EMI courses could significantly predict the research participants' lesson comprehension.

Qualitative data analysis was analysed based on the steps of data analysis suggested by (Creswell, 2012). Firstly, audio recordings and fieldnotes were transcribed. Data was then closely examined for the general sense. Manually open coding technique was employed. Data was next checked for similarity and differences, and then categorized under themes. Theme labels were generated with the reference of the themes obtained from the review of literature. The items that relevant to the factors hindering students' lesson comprehension in EMI classes were selected for analysis in this paper.

\section{RESULTS AND DISCUSSION}

\section{Lesson Comprehension in EMI Classes at Hoa Sen University}

Table 2. Lesson Comprehension in EMI Classes 


\begin{tabular}{lrrrrr}
\hline & Frequency & Percent & Valid Percent & $\begin{array}{c}\text { Cumulative } \\
\text { Percent }\end{array}$ \\
\hline Valid & $10 \%$ & 4 & 1.7 & 1.7 & 1.7 \\
\cline { 2 - 6 } & $20 \%$ & 2 & .9 & .9 & 2.6 \\
\hline $30 \%$ & 14 & 6.0 & 6.0 & 8.6 \\
\hline & $40 \%$ & 19 & 8.2 & 8.2 & 16.8 \\
\hline & $50 \%$ & 33 & 14.2 & 14.2 & 31.0 \\
\hline & $60 \%$ & 46 & 19.7 & 19.8 & 50.9 \\
\hline & $70 \%$ & 55 & 23.6 & 23.7 & 74.6 \\
\hline & $80 \%$ & 44 & 18.9 & 19.0 & 93.5 \\
\hline Missing & $90 \%$ & 11 & 4.7 & 4.7 & 98.3 \\
\hline & $100 \%$ & 4 & 1.7 & 1.7 & 100.0 \\
\hline & Total & 232 & 99.6 & 100.0 & \\
\hline
\end{tabular}

Descriptive analysis of lesson comprehension in EMI classes shows that among 232 research participants gave the responses to the questions about the degree they could comprehend lessons taught in English (10-point scale). Only $1.7 \%$ indicated that they totally understand the lessons (100\%). 83.2\% percent of the respondents mentioned that they understand the lessons in EMI classes $50 \%$ or more, with the highest figure lies in those who understand $70 \%$ of the lesson $(23.7 \%) .16 .8 \%$ showed that they faced lots of difficulties in lesson comprehension (40\% or less).

The findings were almost in line with those of a study conducted on 370 undergraduate students in Taiwan by Chang (2010). Chang found that very few (5.8\%) students are able to understand completely the lectures in English and only 24\% students think that they understand approximately 75 percent and around $40 \%$ of the students comprehend the degree of content achievement between 50 to 74 percent.

The findings revealed that learners of EMI classes quite negatively reflect the content comprehension in EMI lectures. Due to the lack of academic knowledge achievement, learners show their preference in lectures taught in their mother tongues than in English (AlKahtany et al., 2016). Furthermore, students in countries that English is a foreign language were found to face more challenges in lesson comprehension in EMI classes that those who live in countries English is more pervasively used (Keuk \& Tith, 2013). The lack of adequate English level may make students unwilling to take EMI classes because they perceived that taking EMI classes substantially hindered their knowledge absorption (Kim \& Kim, 2014).

\section{The Difficulties Students Faced in EMI Courses}

Table 3 shows ten different factors hindering students' lesson comprehension in EMI classes using 5-point Likert-type scale from 1(Strongly disagree) - 5 (Strongly agree) with 3 representing neither agree nor disagree.

Table 3. Difficulties in EMI courses

\begin{tabular}{ccccc} 
Items & N & Mean & $\begin{array}{c}\text { Std. } \\
\text { Deviation }\end{array}$ \\
\hline
\end{tabular}




\begin{tabular}{|c|c|c|c|c|}
\hline 1 & I receive less interaction and feedback from lecturers. & 233 & 2.55 & 1.016 \\
\hline 2 & I cannot listen and comprehend lectures. & 233 & 2.75 & 1.016 \\
\hline 3 & $\begin{array}{l}\text { I cannot read and comprehend textbooks and related } \\
\text { materials. }\end{array}$ & 233 & 2.82 & .994 \\
\hline 4 & I have difficulties to access related materials. & 232 & 2.86 & 1.230 \\
\hline 5 & $\begin{array}{l}\text { I cannot digest a great amount of content knowledge in } \\
\text { limited time. }\end{array}$ & 233 & 2.87 & 1.079 \\
\hline 6 & $\begin{array}{l}\text { I cannot enjoy the lessons because of passive teaching } \\
\text { methods. }\end{array}$ & 229 & 2.88 & 1.124 \\
\hline 7 & $\begin{array}{l}\text { I cannot understand lectures because of lecturers' poor } \\
\text { pronunciation and fast speed. }\end{array}$ & 231 & 2.92 & 1.085 \\
\hline 8 & $\begin{array}{l}\text { I cannot speak full sentences with average speed and } \\
\text { accurate grammar. }\end{array}$ & 233 & 3.11 & 1.154 \\
\hline 9 & I cannot understand vocabulary in textbooks and lectures. & 232 & 3.47 & 1.139 \\
\hline 10 & $\begin{array}{l}\text { I cannot write a logical paragraph/ essay with various use } \\
\text { of vocabulary and critical thinking. }\end{array}$ & 232 & 3.50 & 1.002 \\
\hline
\end{tabular}

It is surprising that the mean score of 7 out of 10 difficulties listed are under theoretical midpoint $(M=3.0)$. The figures indicate that Hoa Sen University students face quite a few difficulties in EMI classes. The findings show that the variable "I receive less interaction and feedback from lecturers" $(\mathrm{M}=2.55)$ is the lowest. This shows the difference with Joe and Lee findings (2012) when 74\% Korean engineering students reported they received lack of lecturers' interaction and feedback. This could be the result of the university's long-term strategy setting qualified teaching as the highest priority and instructors are equipped with teaching pedagogical approaches through trainings, discussions, workshops, and symposiums. Some other findings are "I cannot listen and comprehend lectures" and " $I$ cannot read and comprehend textbooks and related materials" with $\mathrm{M}=2.75$ and $\mathrm{M}=2.82$ respectively. According to Keuk and Tith (2013), university students often struggled with academic reading activities. Besides, Kagwesage (2013) found out $77 \%$ students admitted their listening skills were insufficient and 98\% EMI instructors believed students were unable to listen English lecture comprehensively. However, the findings show Hoa Sen University students seemed to have fewer difficulties in reading and listening.

Some others factors with higher mean scores are "I have difficulties to access related materials" $(\mathrm{M}=2.86)$, "I cannot digest a great amount of content knowledge in limited time" $(\mathrm{M}=2.87)$ and "I cannot enjoy the lesson because of passive teaching method" $(\mathrm{M}=2.88)$. The results show a lack of agreement with previous researches when passive teaching methods displayed the most problematic for EMI students. In Kim, Kweon and Kim (2017)'s study, very few students thought their EMI classes were as interactive or satisfactory as their classes conducted in their native language. Nevertheless, the mean score of "I cannot understand lecture because of lecturers' poor pronunciation and fast speed" $(\mathrm{M}=2.92)$ is noticeable. This was supported by study of Kim, Kweon and Kim (2017) that more than 40\% Korean research students were positive with their instructors' language ability while only around $10 \%$ evaluated it negatively. The finding also indicated that lecturers' oral skills are not a significant problem inhibiting students' understanding their lessons.

Kagwesage (2013) indicated that students' speaking abilities are not sufficient for EMI courses as they are only able to produce 'single word utterance' (p.66). Moreover, students tend to be less confident with their speaking skills (Keuk \& Tith, 2013). Similarly, the 
findings of this research also reveal that most students have difficulties in speaking full sentences with average speed and accurate grammar in EMI courses with $M=3.11$. The highest difficulty that the research participants face in the study is understanding vocabulary in textbooks and lectures with mean score $=3.47$. The findings show the similarities with Chang (2010) and Rogier (2012) which asserted students have problem with understanding EMI lessons because of insufficient vocabulary knowledge. Finally, "I cannot write a logical paragraph/ essay with various use of vocabulary and critical thinking" $(\mathrm{M}=3.5)$ was found as the most difficult factor for students to deal with in EMI class. Likewise, Al-Kahtany et al. (2016) pointed out Arabic university students lacked sufficient writing skills in terms of ideas, critical thinking, and vocabulary. The Correlation between Variables of Difficulties Students Faced in EMI Courses and
EMI Lesson Comprehension

Table 4. Regression Analysis Summary of Variables Predicting Lesson Comprehension

\begin{tabular}{|c|c|c|c|c|c|c|}
\hline \multirow{2}{*}{$\begin{array}{ll} & \text { Variable } \\
\text { (Constant) }\end{array}$} & \multirow{2}{*}{$\begin{array}{c}\text { B } \\
10.131\end{array}$} & \multicolumn{2}{|c|}{$95 \% \mathrm{CI}$} & \multirow[t]{2}{*}{$\beta$} & \multirow{2}{*}{$\begin{array}{c}\mathbf{t} \\
21.747\end{array}$} & \multirow{2}{*}{$\begin{array}{l}\mathbf{p} \\
.000\end{array}$} \\
\hline & & 9.213 & 11.049 & & & \\
\hline $\begin{array}{l}\text { I cannot understand vocabulary in } \\
\text { textbooks and lectures. }\end{array}$ & -.136 & -.339 & .067 & -.086 & -1.323 & .187 \\
\hline $\begin{array}{l}\text { I cannot read and comprehend textbooks } \\
\text { and related materials. }\end{array}$ & -.251 & -.511 & .009 & -.138 & -1.903 & .058 \\
\hline $\begin{array}{l}\text { I cannot write a logical paragraph/ essay } \\
\text { with various use of vocabulary and } \\
\text { critical thinking. }\end{array}$ & .135 & -.088 & .358 & .075 & 1.196 & .233 \\
\hline $\begin{array}{l}\text { *I cannot speak full sentences with } \\
\text { average speed and accurate grammar. }\end{array}$ & -.303 & -.492 & -.113 & -.194 & -3.154 & .002 \\
\hline *I cannot listen and comprehend lectures. & -.471 & -.735 & -.207 & -.266 & -3.516 & .001 \\
\hline $\begin{array}{l}\text { I cannot understand lectures because of } \\
\text { lecturers' poor pronunciation and fast } \\
\text { speed. }\end{array}$ & -.150 & -.372 & .073 & -.090 & -1.323 & .187 \\
\hline $\begin{array}{l}\text { I receive less interaction and feedback } \\
\text { from lecturers. }\end{array}$ & -.104 & -.342 & .133 & -.059 & -.868 & .386 \\
\hline $\begin{array}{l}\text { I cannot enjoy the lessons because of } \\
\text { passive teaching methods. }\end{array}$ & .110 & -.099 & .318 & .068 & 1.034 & .302 \\
\hline $\begin{array}{l}\text { *I cannot digest a great amount of } \\
\text { content knowledge in limited time. }\end{array}$ & -.316 & -.566 & -.065 & -.189 & -2.487 & .014 \\
\hline $\begin{array}{l}\text { I have difficulties to access related } \\
\text { materials. }\end{array}$ & .114 & -.072 & .301 & .078 & 1.209 & .228 \\
\hline Note: $R^{2}=.410 ; F=14.994 ;{ }^{*} p<.05$ & & & & & & \\
\hline
\end{tabular}

Standard multiple regression analysis was implemented to explore the correlation between variables of difficulties students faced in EMI courses and the overall EMI lesson comprehension and to evaluate how well items of difficulties could significantly predict the research participants' lesson comprehension. The results indicated that the model was statistically significant, $F(10,216)=14.994, p<.001$, and explained for 41 percent of the variation for the EMI lesson comprehension $\left(R^{2}=.410\right)$. The results from the regression 
indicated that, among the variables added, three of them did significantly predict value of lesson comprehension. These included "I cannot speak full sentences with average speed and accurate grammar" $(\mathrm{Beta}=-.303, \mathrm{t}=-3.154, \mathrm{p}<.05)$, "I cannot listen and comprehend lectures" (Beta $=-.471, \mathrm{t}=-3.516, \mathrm{p}<.05)$, and "I cannot digest a great amount of content knowledge in limited time" (Beta $=-.316, \mathrm{t}=-2.487, \mathrm{p}<.05)$. The findings indicated that the inability of listening and comprehending lectures makes the strongest contribution in explaining the dependent variable when controlling other variables in the model. This shows that listening skill plays the most important roles in hindering the learners in comprehending the lesson content in EMI classes. The result is in line with Kim, Kweon and Kim (2017) and Phuong and Nguyen (2019) that listening skill presented the largest problems that EMI students' face and low English listening competence hampered EMI students from understanding their instructors' explanations, leading to failure of the content knowledge comprehension.

Beyond the findings from quantitative data analysis, data from the qualitative data showed some additional worth-noting causes leading to the difficulties in comprehending EMI lessons. First and foremost, insufficient vocabulary range was mentioned by a couple of the research participants to be one of the most influential factors leading to the lack of lessonfully understanding. Research informants showed their dissatisfaction about the great amount of specialized words in EMI courses. This made them struggle with the lecture. One student revealed: "EMI courses make me overwhelmed as there are too many specialized words that I have to learn and remember. Even when I have not remembered the previous words yet, I have to get used to with new ones." However, responses among the informants were not consistent. While some believed that students should be taught common words useful for daily conversation, some claimed that thanks to EMI courses, they could learn many useful words and expand their vocabulary bank for understanding lessons effectively.

Inadequate writing skill was another noticeable issue. Students participating into the study admitted that insufficient writing skills affected their lesson comprehension. Particularly, note-taking considered as the biggest hurdle of writing skills hindered their comprehension. Some expressed they did not know how to note down key words and main ideas of lectures. Some interviewees raised their voice "Before taking EMI course, school should employ some trial classes to let students practice necessary study skills, so they could handle the content knowledge better". Meanwhile, other participants complained the way their lecturers presented the Power-point slide containing too many words made it hard for them to figure out the important points to note down "I suppose my lecturer should show the Power-point slide including only main content and illustration images".

The way lecturers delivered the lessons also caused difficulties for lesson comprehension. The participants claimed that the problems associated with lecturers' oral skills such as the fast speed when delivering lectures and the poor vocabulary usage hinder their comprehension during class time. One participant mentioned "I have tried to understand the lessons as much as I can but sometimes my lecturers talk too fast for me to catch up with the content." This is supported by Goodman (2014) and Kagwasage (2012) that rapid instruction speed would pause students' understanding. Another student supposed that professors should adjust their speed suitably based on the importance extent of the content "I think lecturers should slow down and repeat the significant ideas instead of surfing the content too fast". Besides, students hoped their lecturers could use a wide range of vocabularies in order to make the lessons clear rather than sticking to the content in textbook which is literally hard to obtain "I would like my lecturers use different words from the textbook to make the content sound familiar and easy for us."

Teaching methods were also found to play an important role in comprehension of Hoa Sen University students. This finding is similar to the studies of Goodman (2014) and Hu and Lei (2014). Some interviewees, for example, were dissatisfied with the lecture-style and teacher-led teaching methods in their current EMI courses as these teaching approaches 
hindered their comprehension. These interviewees revealed that their lecturers basically explained the lesson content composed on the Power-point slides, extracted from the textbook without creating interactive or inquiry-based activities. Therefore, they tended to feel bored with the passive ways of receiving knowledge and made no effort at understanding the lecture. This is indicated by some informants as "I wish my class would contain many interesting activities so that whole class would be more excited and engage in the lesson" and "I would like to join in class activities because I think it is the best way to learn".

\section{CONCLUSION AND IMPLICATIONS}

The research aimed to find out the factors hindering students' lesson comprehension in EMI classes at Hoa Sen University. It also attempted to look for the extent that variables of difficulties could predict EMI lesson comprehension. Descriptive statistics revealed that inadequate writing skills, limited vocabulary range, and inadequate speaking skills are three major challenges to students. Particularly, multiple regression analysis pointed out that language skills, including listening and speaking, together with content knowledge are those of making contribution in explaining the understanding ability of the students in EMI classes.

This study has highlighted the factors of current practices of EMI implementation hindering the learners in lesson comprehension in general. However, the study failed to investigate each aspect profoundly and meticulously and make a comparison between the benefits and costs that the learners gain and pay between EMI classes and classes taught in their mother tongues. Future researches should consider researching deeply and extensively each aspect such as lecturers' perspectives, learners' characteristics, EMI approach policies and other potential aspects at different university contexts. Future researches would also make a great contribution if taking benefits and costs that the learners gain and pay in EMI classes and classes taught in their mother tongues into careful consideration.

This study can be a reliable source for the relevant stakeholders to consider how to design an appropriate EMI curriculum and take account of EMI policies that not only meet the students' needs but also the demand of EMI implementation at HEIs. Since students complained about the gap between their own English abilities and English level required in EMI courses "Sometimes I found the course is not for students who had low English proficiency, I prefer learning this course whenever my English is good enough", EMI courses of specific subjects should be organized in accordance with the students' language abilities, from low to high proficiency level in a professional manner.

The study has showed that it is necessary to provide academic assistance such as EMI course orientation, language skills center, EMI learning forum, etc. for students to better equip them with both the language and knowledge needed. Recommendations and expectation of participants are that "if I were prepared with a short course of how to learn EMI subjects, I believed I could deal well with any EMI courses" and "I would like to have a teaching assistant in my class, so whenever I could not keep up with the lesson I could ask again".

To limit the challenges that students face in EMI classes, instructors should be more flexible to adapt appropriate teaching methods for EMI curricula. The instructor should be highly aware of their students' troubles in EMI courses in order to develop alternative efficient teaching techniques to obtain students' lesson comprehension and inspire students with language learning. One of students' shares "The passive teaching method makes me bored and exhausted while attending the EMI class. I wish my lecturer could create some activities to warm the environment up and make students eager in lessons" and "I think teaching styles influences too much how students understand and enjoy the lessons".

\section{REFERENCES}

Alanshory, A. S. (2014). The effectiveness of using English as medium of instruction: An issue in Malaysia. Academia, 1-14. 
Al-Kahtany, A. H., Faruk, S. M. G., \& Al Zumor, A. W. Q. (2016). English as the medium of instruction in Saudi higher education: Necessity or hegemony? Journal of Language Teaching and Research, 7(1), 49-58.

Berg, B. L. (2001). Qualitative research methods for the social sciences. Long Beach: California State University.

Bradford, A. (2013). English-medium degree programs in Japanese universities: Learning from the European experience. Asian Education and Development Studies, 2(3), 225-240.

Bradford, A. (2019). It's not all about English! The problem of language foregrounding in Englishmedium programmes in Japan. Journal of Multilingual and Multicultural Development, 40(8), 707-720.

Byun, K., \& Kim, M. (2011). Shifting patterns of the government's policies for the internationalization of Korean higher education. Journal of Studies in International Education, 15(5), 467-486.

Byun, K., Chu, H., Kim, M., Park, I., Kim, S., \& Jung, J. (2011). English-medium teaching in Korean higher education: Policy debates and reality. Higher Education, 62(4), 431-449.

Chang, Y. Y. (2010). English-medium instruction for subject courses in tertiary education: Reactions from Taiwanese undergraduate students. Taiwan International ESP Journal, 2(1), 53-82.

Chuang, Y. T. (2015). An EMI pedagogy that facilitates students' learning. English Language Teaching, 8(12), 63-73.

Civan, A., \& Coşkun, A. (2016). The effect of the medium of instruction language on the academic success of university students. Educational Sciences: Theory \& Practice, 16(6), 1981-2004.

Corrales, K. A., Rey, L. A. P., \& Escamilla, N. S. (2016). Is EMI enough? Perceptions from university professors and students. Latin American Journal of Content \& Language Integrated Learning, 9(2), 318-344.

Coxhead, A., \& Boutorwick, T. J. (2018). Longitudinal vocabulary development in an EMI international school context: Learners and texts in EAL, Maths, and Science. TESOL Quarterly, 52(3), 588-610.

Creswell, J. W. (2012). Educational research: Planning, conducting, and evaluating quantitative and qualitative research (4th ed.). Boston: Pearson Education Ltd.

Dearden, J. (2014). English as a medium of instruction-a growing global phenomenon. British Council.

Dorasamy, R. S. (2012). The impact of English as medium of instruction on the academic performance of second language learners in the Further Education and Training band at schools in KwaZulu-Natal.? (Doctoral dissertation, Durban University of Technology, 2012). Retrieved from http://openscholar.dut.ac.za/bitstream/10321/758/1/Dorasamy_2012.pdf.

Galloway, N., Kriukow, J., \& Numajiri, T. (2017). Internationalisation, higher education and the growing demand for English: an investigation into the English medium of instruction (EMI) movement in China and Japan. London: British Council.

Goodman, B. A. (2014). Implementing English as a medium of instruction in a Ukrainian University: Challenges, adjustments, and opportunities. International Journal of Pedagogies and Learning, 9(2), 130-141.

Government of Vietnam. (2008). Quyết định số 1400/QĐ-TTG của Thủ tướng Chính phủ về việc phê duyệt Đề án "Dạy và học ngoại ngữ trong hệ thống giáo dục quốc dân giai đoạn 2008 - 2020" [Decision No. 1400/QD-TTG on "Teaching and learning foreign languages in the national education system, period 2008 - 2020"]. Hanoi: Government of Vietnam.

Graddol, D. (1997). The future of English? London: British Council.

Hellekjær, G. O. (2010). Lecture comprehension in English-medium higher education. HERMESJournal of Language and Communication in Business, 45, 11-34. 
Hesse-Biber, S. N. (2010). Mixed methods research: Merging theory with practice. New York: Guilford Press.

Hu, G. (2019). English-medium instruction in higher education: Lessons from china. Journal of Asia TEFL, 16(1), 1-11.

Hu, G., \& Lei, J. (2014). English-medium instruction in Chinese higher education: A case study. Higher Education, 67(5), 551-567.

Huang, D. F. (2015). Exploring and assessing effectiveness of English medium instruction courses: The students' perspectives. Procedia-Social and Behavioral Sciences, 173, 71-78.

Ibrahim, J. (2001). The implementation of EMI (English medium instruction) in Indonesian universities: Its opportunities, its threats, its problems, and its possible solutions. $k @ t a$ lama, 3(2), 121-138.

Joe, Y., \& Lee, H. K. (2013). Does English-medium instruction benefit students in EFL contexts? A case study of medical students in Korea. The Asia-Pacific Education Researcher, 22(2), 201207.

Kagwesage, A. M. (2013). Coping with learning through a foreign language in Higher education in Rwanda. (Doctoral dissertation, Linköping University, 2013). Retrieved from http://www.diva-portal.org/smash/record.jsf?pid=diva2\%3A612253\&dswid=-2234

Keuk, C. N., \& Tith, M. (2013). The enactment of English-medium instruction (EMI) undergraduate program in Cambodia. International Journal of Innovation in English Language Teaching and Research, 2(2), 160-175.

Kim, E. G., Kweon, S. O., \& Kim, J. (2017). Korean engineering students' perceptions of Englishmedium instruction (EMI) and L1 use in EMI classes. Journal of Multilingual and Multicultural Development, 38(2), 130-145.

Kim, I., \& Kim, M. H. (2014). Students' perceptions of EMI in higher education in Korea. Journal of Asia TEFL, 11(2), 35-61.

Kyeyune, R. (2010). Challenges of using English as a medium of instruction in multilingual contexts: A view from Ugandan classrooms. Language, Culture and Curriculum, 16(2), 173-184.

Le, T.T.N. (2019) University lecturers' perceived challenges in EMI: Implications for teacher professional development. In H. T. M. Nguyen, T. T. M. Nguyen \& R. Barnard (Eds.), Building teacher capacity in English language teaching in Vietnam: Research, policy and practice (pp. 115-132). Routledge.

Macaro, E., Curle, S., Pun, J., An, J., \& Dearden, J. (2018). A systematic review of English medium instruction in higher education. Language Teaching, 51(1), 36-76.

Mellion, M.J. (2008). The challenge of changing tongues in business university education. In R. Wilkinson \& V. Zegers (ed.). Realizing content and language integration in higher education (pp. 212-227). Maastricht: Maastricht University.

Neuman, W. L. (2007). Basic of social research: Qualitative and quantitative approaches. Essex: Pearson Education Limited.

Nguyen, H. T., Walkinshaw, I., \& Pham, H. H. (2017). EMI programs in a Vietnamese university: Language, pedagogy and policy issues. In B. Fenton-Smith, P. Humphreys \& I. Walkinshaw (Ed.), English medium instruction in higher education in Asia-Pacific (pp. 37-52). Springer International Publishing.

Pallant, J. (2013). SPSS Survival Manual: A step by step guide to data analysis using SPSS for windows $\left(5^{\text {th }}\right.$ edition). New York: Open University Press.

Pham, T. N. (2014). Foreign language policy. In L. T. Tran, S. Marginson, H. M. Do, Q. T. N. Do, T. T. T. Le, N. T. Nguyen, T. T. P. Vu, T. N. Pham, \& H. T. L. Nguyen (Eds.), Higher education in Vietnam: Flexibility, mobility and practicality in the global knowledge economy (pp. 169186). Basingstoke: Palgrave Macmillan. 
Phuong, Y. H., \& Nguyen, T. T. (2019). Students' perceptions towards the benefits and drawbacks of EMI classes. English Language Teaching, 12(5), 88-100.

Phuong, Y. H., \& Nguyen, T. T. (2019). Students' Perceptions towards the Benefits and Drawbacks of EMI Classes. English Language Teaching, 12(5), 88-100.

Rogier, D. (2012). The effects of English-medium instruction on language proficiency of students enrolled in higher education in the UAE. (Doctoral dissertation, University of The University of Exeter, 2012). Retrieved from

https://ore.exeter.ac.uk/repository/bitstream/handle/10036/4482/RogierD.pdf?s

Rose, H., Curle, S., Aizawa, I., \& Thompson, G. (2019). What drives success in English medium taught courses? The interplay between language proficiency, academic skills, and motivation. Studies in Higher Education, 1-13.

Vu, N. T., \& Burns, A. (2014). English as a medium of instruction: Challenges for Vietnamese tertiary lecturers. Journal of Asia TEFL, 11(3), 1-31.

Wächter, B., \& Maiworm, F. (2002). English-language-taught degree programmes in European higher education: Trends and success factors. ACA Papers on International Cooperation in Education. Bonn: Lemmens.

Wächter, B., \& Maiworm, F. (2008). English-taught programmes in European higher education: The picture in 2007. ACA Papers on International Cooperation in Education. Bonn: Lemmens.

Wächter, B., \& Maiworm, F. (Eds.). (2014). English-taught programmes in European higher education: The state of play in 2014. ACA Papers on International Cooperation in Education. Bonn: Lemmens.

Wilkinson, R. (2005). The impact of language on teaching content: Views from the content teacher. Paper presented at Bi-and Multilingual Universities-Challenges and Future Prospects. Helsinki, Finland.

Wilkinson, R. (2013). English-medium instruction at a Dutch university: Challenges and pitfalls. In A. Doiz, D. Lasagabaster \& J. M. Sierra (Eds.), English-medium instruction at universities: Global challenges (pp. 3-24). Bristol: Multilingual Matters.

\section{$\underline{A U T H O R S}$ 'BIO}

Tran Ngoc Tien, PhD, is a university instructor of the Department of English Language Studies, Hoa Sen University, Vietnam. He graduated from Ritsumeikan Asia Pacific University in Japan and has more than 15 years of teaching at various levels. He has published a couple of papers in Japan, America and England and joined numerous conferences worldwide. His interests of researching are educational attainment, job satisfaction, learning motivation, language learning and teaching.

Tran Thi Bao Trinh was a former student of English Language Studies of Hoa Sen University. She has just graduated from the undergraduate level of Hoa Sen University and on her way of preparing for her higher education. Her research interests include second language teaching, bilingual education, psychology of second language learners and voluntary second language teaching in Vietnam.

Bien Thi Thanh Mai, (MA. TESOL, University of Melbourne), is a lecturer in the Department of English Language Studies at Hoa Sen University in Vietnam. She is an inservice teacher trainer and the coordinator of English language teaching strand. Her research interests include English language writing, teacher professional development, and teaching English in different contexts. 